\title{
Immune checkpoint inhibitors in the treatment of virus-associated cancers
}

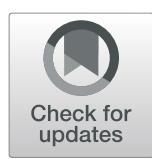

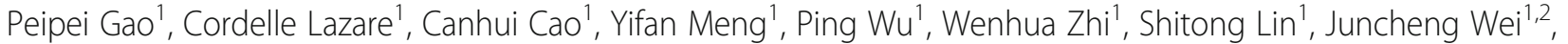 \\ Xiaoyuan Huang ${ }^{1,2}$, Ling $\mathrm{Xi}^{1,2}$, Gang Chen ${ }^{1,2}$, Junbo $\mathrm{Hu}^{2}$, Ding $\mathrm{Ma}^{1,2^{*}}$ and Peng $\mathrm{Wu}^{1,2^{*}}$
}

\begin{abstract}
Among all malignant tumors that threaten human health, virus-related tumors account for a large proportion. The treatment of these tumors is still an urgent problem to be resolved. The immune system is the "guard" of the human body, resisting the invasion of foreign substances such as viruses. Studies have shown that immunotherapy has clinical significance in the treatment of a variety of tumors. In particular, the emergence of immune checkpoint inhibitors (ICls) in recent years has opened a new door to cancer therapy. Considering the potential role of ICls in the treatment of virus-related cancers, we focused on their therapeutic effect in virus-associated cancers and explored whether the therapeutic effect in virus-associated cancers was related to virus infection status. Although there is no clear statistical significance indicates that $\mathrm{ICl}$ are more effective in virus-associated cancers than nonvirus infections, the efficacy of checkpoint inhibitors in the treatment of virus-related cancers is promising. We believe that this research provides a good direction for the implementation of individualized precision medicine.
\end{abstract}

Keywords: Immunotherapy, Immune checkpoint inhibitors, Virus-associated cancers

\section{Background}

Cancer is a major public health problem worldwide. According to the International Agency for Research on Cancer (IARC), there were about 18.1 million new cancer cases and 9.6 million cancer deaths in 2018 worldwide [1]. Carcinogenic viral infection is an important cause of cancer, especially in developing countries. Approximately $20 \%$ of all human cancers were attributable to carcinogenic viruses [2]. Seven viruses have been classified as well established carcinogenic viruses in human beings by the IARC [3]: human papillomavirus (HPV), hepatitis B virus (HBV), hepatitis C virus (HCV), Epstein-Barr virus (EBV), human herpesvirus type 8 (HHV-8, also known as Kaposi's sarcoma herpesvirus), HIV type 1 (HIV-1), and human T cell lymphotropic virus type 1 (HTLV-1). Among them, the most important infectious viruses worldwide are HPV, HBV, HCV, and EBV.

\footnotetext{
* Correspondence: dma@tjh.tjmu.edu.cn; pengwu8626@tjh.tjmu.edu.cn ${ }^{1}$ Cancer Biology Research Center (Key Laboratory of the Ministry of Education), Tongji Hospital, Tongji Medical College, Huazhong University of Science and Technology, Wuhan, Hubei, China

Full list of author information is available at the end of the article
}

Even though these carcinogenic viruses belong to different genus and use multiple mechanisms to promote cancer development, they may have several features in common $[4,5]$. They have the ability to infect host cell and establish persistent infection. During this process, they have evolved strategies for virus replication and persistence, including evading the host immune surveillance, creating conditions for virus replication, and ensuring correct replication. More specifically, immune escape mechanisms include producing anti-inflammatory cytokines, inducing regulatory $\mathrm{T}$ (Treg) cells, and increasing the expression of immune checkpoint proteins.

Immune checkpoints mainly including programmed death 1 (PD-1) and cytotoxic $\mathrm{T}$ lymphocyte antigen 4 (CTLA-4) are membrane-bound molecules expressed on immune cells. Immune checkpoint inhibitors (ICIs) are predominantly monoclonal antibodies, which have shown to be effective in a variety of cancers [6-11]. They function to block the binding of immune checkpoint molecules to their ligands, reversing the inactivation of $\mathrm{T}$ cells, enhancing the immune response of $\mathrm{T}$ cells, and resisting foreign aggression such as virus infections. Theoretically, they could assist in virus clearance in infected patients and may have a greater effect in virus-associated cancers.

(c) The Author(s). 2019 Open Access This article is distributed under the terms of the Creative Commons Attribution 4.0 International License (http://creativecommons.org/licenses/by/4.0/), which permits unrestricted use, distribution, and 
Therefore, ICIs are of concern to us and may have special effects in virus-associated cancers.

The ICIs approved by the Food and Drug Administration (FDA) include anti-PD-1 (nivolumab and pembrolizumab), anti-PD-L1 (atezolizumab, avelumab, and durvalumab), and anti-CTLA-4 (ipilimumab and tremelimumab). There are a series of clinical trials involving the efficacy of ICIs in virus-related cancers. Published clinical trials evaluating the efficacy of ICIs were summarized in Table 1, and the ongoing clinical trials were listed in Table 2.

\section{HPV-associated cancers}

Human papillomavirus (HPV) is a circular DNA virus, which infects the genital mucosa, the oral mucosa, and the basal keratinocytes of the skin, mainly spreading by sexual contact. It was reported that HPV caused more than half of all infection-attributable cancers in women worldwide [3]. It is a common pathogen of cancers including cervix, vaginal, vulvar, anal, penile, and oropharyngeal cancers [28]. Although the incidence rate of cervical cancer in developed countries has been declining due to cancer screening programs and vaccination programs, the incidence rates of HPV-associated oropharyngeal, anal, and vulvar cancers increased from 2000 to 2009 [29]. Despite the wide use of multiple treatment options, most HPV-related cancers are still difficult to cure around the world. According to the National Comprehensive Cancer Network (NCCN) Clinical Practice Guidelines in Oncology, surgical resection is the treatment of choice for early stage cancers and chemoradiotherapy is the standard treatment for locally advanced diseases. However, traditional treatment options such as systemic chemotherapy, surgery, and radiotherapy have limited effect for patients who have recurrent or metastatic cancers. The emergence of ICIs in recent years provides new hope for the treatment of these cancers.

In 2018, the FDA approved pembrolizumab for recurrent or metastatic cervical cancer based on results from

Table 1 Published clinical trials evaluating ICls in virus-related cancers

\begin{tabular}{|c|c|c|c|c|}
\hline Viruses & $\mathrm{ICls}$ & Cancers & Response rates & Ref. \\
\hline \multirow[t]{9}{*}{ HPV } & Pembrolizumab & R/M cervical cancer & $17 \%$ & [12] \\
\hline & Nivolumab & GYN cancers & $20.8 \%$ & [13] \\
\hline & Nivolumab & SCCA & $24 \%$ & [14] \\
\hline & \multirow[t]{3}{*}{ Pembrolizumab } & R/M HNSCC & $18 \%$ & [15] \\
\hline & & HPV-positive & $25 \%$ & \\
\hline & & HPV-negative & $14 \%$ & \\
\hline & \multirow[t]{3}{*}{ Durvalumab } & R/M HNSCC & $16.2 \%$ & [16] \\
\hline & & HPV-positive & $29.4 \%$ & \\
\hline & & HPV-negative & $10.8 \%$ & \\
\hline \multirow[t]{6}{*}{$\mathrm{HBV} / \mathrm{HCV}$} & Nivolumab & HCV infection & $11.1 \%$ & [17] \\
\hline & Tremelimumab & $\mathrm{HCC}$ & $17.6 \%$ & [18] \\
\hline & Tremelimumab & $\mathrm{HCC}$ & $26.3 \%$ & [19] \\
\hline & Nivolumab & $\mathrm{HCC}$ & $15 \%-20 \%$ & [20] \\
\hline & & HBV/HCV-positive & $14-20 \%$ & \\
\hline & & HBV/HCV-negative & $21-23 \%$ & \\
\hline \multirow[t]{6}{*}{ EBV } & Nivolumab & R/M NPC & $20.5 \%$ & [21] \\
\hline & Pembrolizumab & R/M NPC & $25.9 \%$ & [22] \\
\hline & Pembrolizumab & NK/T cell lymphoma & $71.4 \%$ & [23] \\
\hline & Pembrolizumab & $\mathrm{NHL}$ & $23.3 \%$ & [24] \\
\hline & Pembrolizumab & EBV-positive GC & $100 \%$ & [25] \\
\hline & Nivolumab & EBV-negative GC & $25 \%$ & [26] \\
\hline \multirow[t]{2}{*}{ HIV } & Nivolumab & Cancer (HIV-positive) & $27 \%-63 \%$ & [27] \\
\hline & Ipilimumab & & & \\
\hline HTLV-1 & & Adult T cell lymphoma & & \\
\hline $\mathrm{HHV}-8$ & & Kaposi's sarcoma & & \\
\hline
\end{tabular}

Abbreviations: ICls immune checkpoint inhibitors, HPV human papillomavirus, $H B V$ hepatitis B virus, $H C V$ hepatitis $C$ virus, EBV Epstein-Barr virus, $H H V-8$ human herpesvirus type 8, HTLV-1 human T cell lymphotropic virus type 1, R/M recurrent and/or metastatic, GYN cancers cervical, vaginal, and vulvar cancers, SCCA squamous cell carcinoma of the anal canal, HNSCC head and neck squamous cell carcinoma, HCC hepatocellular carcinoma, NPC nasopharyngeal carcinoma, GC gastric cancer, $N H L$ non-Hodgkin lymphoma 
Table 2 The ongoing clinical trials of ICls in virus-associated cancers

\begin{tabular}{|c|c|c|c|c|}
\hline Trial identifier & Phase & Study title & Treatment & Patients \\
\hline \multicolumn{5}{|c|}{ ICls in HPV-associated cancers } \\
\hline NCT02054806 & I & $\begin{array}{l}\text { Pembrolizumab (MK-3475) in participants with advanced solid } \\
\text { tumors (KEYNOTE-28) }\end{array}$ & Pembrolizumab & Advanced solid tumors \\
\hline NCT01848834 & । & $\begin{array}{l}\text { Pembrolizumab (MK-3475) in participants with advanced solid } \\
\text { tumors (KEYNOTE-012) }\end{array}$ & Pembrolizumab & Advanced Solid Tumors \\
\hline NCT02488759 & $|/| \mid$ & $\begin{array}{l}\text { Nivolumab, and nivolumab Combination Therapy in Virus-associated } \\
\text { Tumors (CheckMate 358) }\end{array}$ & $\begin{array}{l}\text { Nivolumab } \\
\text { Ipilimumab }\end{array}$ & Virus-associated tumors \\
\hline NCT02314169 & ॥ & $\begin{array}{l}\text { Nivolumab with or without ipilimumab in treating patients with } \\
\text { refractory metastatic anal canal cancer ( } \mathrm{NCl} 9673)\end{array}$ & $\begin{array}{l}\text { Ipilimumab } \\
\text { Nivolumab }\end{array}$ & R/M SCCA \\
\hline NCT02105636 & III & $\begin{array}{l}\text { Trial of nivolumab vs therapy of investigator's choice in recurrent or } \\
\text { metastatic head and neck carcinoma (CheckMate 141) }\end{array}$ & Nivolumab & $\mathrm{R} / \mathrm{M} \mathrm{HNC}$ \\
\hline NCT02379520 & । & $\begin{array}{l}\text { HPV-16/18 E6/E7-specific T lymphocytes in patients with relapsed } \\
\text { HPV-associated cancers }\end{array}$ & Nivolumab & HPV-related cancers \\
\hline NCT03841110 & । & $\begin{array}{l}\text { FT500 as monotherapy and in combination with immune checkpoint } \\
\text { inhibitors in subjects with advanced solid tumors }\end{array}$ & $\begin{array}{l}\text { Nivolumab } \\
\text { Pembrolizumab } \\
\text { Atezolizumab }\end{array}$ & Advanced solid tumors \\
\hline NCT03228667 & ॥ & $\begin{array}{l}\text { QUILT-3.055: ALT-803 in combination with PD-1/PD-L1 checkpoint in- } \\
\text { hibitor in patients with advanced cancer }\end{array}$ & $\begin{array}{l}\text { Pembrolizumab } \\
\text { Nivolumab } \\
\text { Atezolizumab } \\
\text { Avelumab }\end{array}$ & Advanced cancers \\
\hline NCT02890368 & I & $\begin{array}{l}\text { Intratumoral injections of TTI-621 in subjects with relapsed and } \\
\text { refractory solid tumors and mycosis fungoides }\end{array}$ & $\begin{array}{l}\text { PD-1/PD-L1 } \\
\text { Inhibitor }\end{array}$ & $\begin{array}{l}\text { HPV-related malignant } \\
\text { neoplasm }\end{array}$ \\
\hline NCT03735290 & $|/| \mid$ & $\begin{array}{l}\text { ILIxadencel administered into tumors in combination with checkpoint } \\
\text { inhibitor (CPI) in patients with advanced cancer (ILIAD) }\end{array}$ & Pembrolizumab & Advanced cancer \\
\hline NCT02632344 & ॥ & $\begin{array}{l}\text { Pembrolizumab for HPV-associated recurrent respiratory papilloma } \\
\text { patients with laryngeal, tracheal, and/or pulmonary involvement }\end{array}$ & Pembrolizumab & $\begin{array}{l}\text { HPV-associated } \\
\text { papilloma patients }\end{array}$ \\
\hline NCT01693783 & ॥ & $\begin{array}{l}\text { Ipilimumab in treating patients with metastatic or recurrent human } \\
\text { papilloma virus-related cervical cancer }\end{array}$ & Ipilimumab & $\begin{array}{l}\text { R/M HPV-related } \\
\text { cervical cancer }\end{array}$ \\
\hline \multicolumn{5}{|c|}{ ICls in HBV/HCV-associated cancers } \\
\hline NCT01853618 & I & Tremelimumab with chemoembolization or ablation for liver cancer & Tremelimumab & Liver cancer \\
\hline NCT01658878 & $|/| \mid$ & $\begin{array}{l}\text { Nivolumab or nivolumab in combination with other agents in patients } \\
\text { with advanced liver cancer (CheckMate040) }\end{array}$ & $\begin{array}{l}\text { Nivolumab } \\
\text { Ipilimumab }\end{array}$ & Advanced liver cancer \\
\hline NCT03841110 & I & $\begin{array}{l}\text { FT500 as monotherapy and in combination with ICls in subjects with } \\
\text { advanced solid tumors }\end{array}$ & $\begin{array}{l}\text { FT500 } \\
\text { Nivolumab } \\
\text { Pembrolizumab } \\
\text { Atezolizumab }\end{array}$ & $\begin{array}{l}\text { Advanced solid } \\
\text { tumors (HCC) }\end{array}$ \\
\hline NCT03228667 & $\|$ & $\begin{array}{l}\text { QUILT-3.055: a study of ALT-803 in combination with PD-1/PD-L1 } \\
\text { checkpoint inhibitor in patients with advanced cancer }\end{array}$ & $\begin{array}{l}\text { Pembrolizumab } \\
\text { Nivolumab } \\
\text { Atezolizumab } \\
\text { Avelumab }\end{array}$ & Advanced cancer \\
\hline NCT03419481 & $\|$ & Pembrolizumab in patients with HBV-related HCC & Pembrolizumab & HBV-related HCC \\
\hline NCT02402699 & $\|$ & $\begin{array}{l}\text { Ipilimumab 60-month pharmacovigilance protocol for advanced } \\
\text { melanoma patients who are hepatitis B and/or hepatitis C virus } \\
\text { positive in Taiwan (Yervoy RMP) }\end{array}$ & Ipilimumab & $\begin{array}{l}\text { Melanoma (HBV/HCV } \\
\text { positive) }\end{array}$ \\
\hline \multicolumn{5}{|c|}{ ICls in EBV-associated cancers } \\
\hline NCT02339558 & $\|$ & Nivolumab in treating patients with recurrent and/or metastatic NPC & Nivolumab & R/M NPC \\
\hline NCT02054806 & । & $\begin{array}{l}\text { Study of pembrolizumab (MK-3475) in participants with advanced } \\
\text { solid tumors (MK-3475-028/KEYNOTE-28) }\end{array}$ & Pembrolizumab & Advanced solid tumors \\
\hline NCT01848834 & । & $\begin{array}{l}\text { Study of pembrolizumab (MK-3475) in participants with advanced } \\
\text { solid tumors (MK-3475-012/KEYNOTE-012) }\end{array}$ & Pembrolizumab & Advanced solid tumors \\
\hline NCT02488759 & $|/| \mid$ & $\begin{array}{l}\text { An investigational immuno-therapy study to investigate the safety } \\
\text { and effectiveness of nivolumab, and nivolumab combination }\end{array}$ & $\begin{array}{l}\text { Nivolumab } \\
\text { Ipilimumab }\end{array}$ & Virus-associated tumors \\
\hline
\end{tabular}


Table 2 The ongoing clinical trials of ICls in virus-associated cancers (Continued)

\begin{tabular}{|c|c|c|c|c|}
\hline Trial identifier & Phase & Study title & Treatment & Patients \\
\hline & & therapy in virus-associated tumors (CheckMate358) & & \\
\hline NCT03258567 & ॥ & $\begin{array}{l}\text { Nivolumab in EBV-positive lymphoproliferative disorders and } \\
\text { EBV-positive NHL }\end{array}$ & Nivolumab & $\begin{array}{l}\text { EBV-positive } \\
\text { lymphoproliferative } \\
\text { disorders } \\
\text { EBV-positive NHL }\end{array}$ \\
\hline NCT02973113 & । & $\begin{array}{l}\text { Combining nivolumab with Epstein-Barr virus-specific T cells } \\
\text { (EBVSTS) in relapsed/refractory EBV-positive lymphoma } \\
\text { patients (PREVALE) }\end{array}$ & Nivolumab & EBV-positive lymphoma \\
\hline NCT03038672 & $\|$ & $\begin{array}{l}\text { Nivolumab with or without varlilumab in treating patients } \\
\text { with relapsed or refractory aggressive B cell lymphomas }\end{array}$ & $\begin{array}{l}\text { Nivolumab } \\
\text { Varlilumab }\end{array}$ & $\begin{array}{l}\text { Aggressive B cell } \\
\text { lymphomas } \\
\text { (EBV-positive) }\end{array}$ \\
\hline NCT03015896 & $|/| \mid$ & $\begin{array}{l}\text { Nivolumab and lenalidomide in treating patients with } \\
\text { relapsed or refractory non-Hodgkin or Hodgkin lymphoma }\end{array}$ & Nivolumab & $\mathrm{NHL}$ or $\mathrm{HL}$ \\
\hline NCT03267498 & ॥ & $\begin{array}{l}\text { Nivolumab + chemoradiation in stage II-IVB nasopharyngeal } \\
\text { carcinoma (NPC) }\end{array}$ & $\begin{array}{l}\text { Nivolumab } \\
\text { Chemoradiation }\end{array}$ & NPC \\
\hline NCT02834013 & ॥ & Nivolumab and ipilimumab in treating patients with rare tumors & $\begin{array}{l}\text { Nivolumab } \\
\text { Ipilimumab }\end{array}$ & NPC \\
\hline NCT03427827 & III & $\begin{array}{l}\text { Adjuvant PD-1 antibody in locoregionally advanced NPC } \\
\text { after chemoradiotherapy }\end{array}$ & PD-1 antibody & NPC \\
\hline NCT03390738 & ॥ & $\begin{array}{l}\text { Nivolumab as treatment for recurrent/metastatic NPC after } \\
\text { failing } 2 \text { lines or more previous chemotherapy }\end{array}$ & Nivolumab & R/M NPC \\
\hline NCT03769467 & I/II & $\begin{array}{l}\text { Tabelecleucel in combination with pembrolizumab in subjects } \\
\text { with EBV+ NPC (ATA129-NPC-202) }\end{array}$ & Pembrolizumab & EBV-positive NPC \\
\hline NCT03586024 & $|/| \mid$ & $\begin{array}{l}\text { Pembrolizumab in patients with relapsed or refractory extranodal } \\
\text { NKJT cell lymphoma (ENKTL), nasal type, and EBV-associated } \\
\text { diffuse large B cell lymphomas }\end{array}$ & Pembrolizumab & $\begin{array}{l}\text { EBV-associated } \\
\text { diffuse large B } \\
\text { cell lymphomas }\end{array}$ \\
\hline NCT03257163 & $\|$ & $\begin{array}{l}\text { Pembrolizumab, capecitabine, and radiation therapy in treating } \\
\text { patients with mismatch repair-deficient and EBV-positive } \\
\text { gastric cancer }\end{array}$ & Pembrolizumab & EBV-positive GC \\
\hline NCT03544099 & $\|$ & $\begin{array}{l}\text { Pembrolizumab for nasopharyngeal carcinoma patients with } \\
\text { detectable plasma Epstein-Barr virus DNA }\end{array}$ & Pembrolizumab & EBV-positive NPC \\
\hline NCT03813394 & $|/| \mid$ & $\begin{array}{l}\text { Bevacizumab and pembrolizumab combination in EBER-ISH } \\
\text { positive NPC (2018/00947) }\end{array}$ & Pembrolizumab & NPC \\
\hline NCT03160079 & $|/| \mid$ & $\begin{array}{l}\text { Blinatumomab and pembrolizumab for adults with relapsed/ } \\
\text { refractory B cell acute lymphoblastic leukemia with high } \\
\text { marrow lymphoblasts }\end{array}$ & Pembrolizumab & $\begin{array}{l}\text { Relapsed/refractory } \\
\text { B cell ALL }\end{array}$ \\
\hline NCT02950220 & । & $\begin{array}{l}\text { Pembrolizumab and ibrutinib in treating patients with relapsed } \\
\text { or refractory non-Hodgkin lymphoma }\end{array}$ & Pembrolizumab & $\begin{array}{l}\text { Relapsed or } \\
\text { refractory NHL }\end{array}$ \\
\hline NCT03491345 & $\|$ & K-basket, avelumab, biomarker-driven, advanced solid tumor & Avelumab & $\begin{array}{l}\text { EBV-positive } \\
\text { mutation tumor }\end{array}$ \\
\hline NCT02875613 & ॥ & Avelumab for recurrent/metastatic nasopharyngeal cancer & Avelumab & $\mathrm{R} / \mathrm{M} N P C$ \\
\hline NCT03735290 & $|/| \mid$ & $\begin{array}{l}\text { Evaluate the safety and effectiveness of ILIxadencel administered } \\
\text { into tumors in combination with checkpoint inhibitor (CPI) in } \\
\text { patients with advanced cancer }\end{array}$ & Pembrolizumab & Advanced cancer \\
\hline ICls in virus-assoc & ciated ca & $-I I V, H T L V, H H V-8)$ & & \\
\hline NCT02408861 & । & $\begin{array}{l}\text { Ipilimumab and nivolumab in advanced HIV-associated solid } \\
\text { tumors with expansion cohorts in HIV-associated solid tumors } \\
\text { and a cohort of HIV-associated classical Hodgkin lymphoma }\end{array}$ & $\begin{array}{l}\text { Nivolumab } \\
\text { Ipilimumab }\end{array}$ & $\begin{array}{l}\text { Advanced HIV-associated } \\
\text { solid tumors }\end{array}$ \\
\hline NCT03316274 & । & $\begin{array}{l}\text { Evaluate the safety, feasibility, and immunologic correlatives of } \\
\text { intra-lesional nivolumab therapy for limited cutaneous } \\
\text { Kaposi sarcoma }\end{array}$ & Nivolumab & $\begin{array}{l}\text { Limited cutaneous } \\
\text { Kaposi sarcoma }\end{array}$ \\
\hline NCT03367754 & । & A single dose of pembrolizumab in HIV-infected people & Pembrolizumab & HIV-infected people \\
\hline & 1 & Pembrolizumab in treating patients with HIV and relapsed & Pembrolizumab & Patients with HIV and \\
\hline
\end{tabular}


Table 2 The ongoing clinical trials of ICls in virus-associated cancers (Continued)

\begin{tabular}{|c|c|c|c|c|}
\hline Trial identifier & Phase & Study title & Treatment & Patients \\
\hline NCT02595866 & & refractory, or disseminated malignant neoplasms & & malignant neoplasms \\
\hline NCT03239899 & I & $\begin{array}{l}\text { PD-1 inhibition to determine CNS reservoir of } \\
\text { HIV-infection }\end{array}$ & Pembrolizumab & HIV infection \\
\hline NCT03767465 & Observational & $\begin{array}{l}\text { Treatment with ICls of HIV-infected subjects with cancer } \\
\text { (PembroHIV) }\end{array}$ & $\mathrm{ICls}$ & $\begin{array}{l}\text { HIV-infected subjects } \\
\text { with cancer }\end{array}$ \\
\hline NCT03075553 & ॥ & $\begin{array}{l}\text { Nivolumab in treating patients with relapsed or refractory } \\
\text { peripheral T cell lymphoma }\end{array}$ & Nivolumab & $\begin{array}{l}\text { Relapsed or refractory } \\
\text { peripheral T cell } \\
\text { lymphoma }\end{array}$ \\
\hline NCT02631746 & ॥ & $\begin{array}{l}\text { Nivolumab in treating patients with HTLV-associated T cell } \\
\text { leukemia/lymphoma }\end{array}$ & Nivolumab & $\begin{array}{l}\text { HTLV-associated T cell } \\
\text { leukemia/lymphoma }\end{array}$ \\
\hline NCT03469804 & ॥ & $\begin{array}{l}\text { Phase II multicentric study of pembrolizumab in classic or } \\
\text { endemic Kaposi's sarcoma }\end{array}$ & Pembrolizumab & $\begin{array}{l}\text { Classic or endemic } \\
\text { Kaposi's sarcoma }\end{array}$ \\
\hline NCT03038672 & $\|$ & $\begin{array}{l}\text { Nivolumab with or without varlilumab in treating patients } \\
\text { with relapsed or refractory aggressive B cell lymphomas }\end{array}$ & $\begin{array}{l}\text { Nivolumab } \\
\text { Varlilumab }\end{array}$ & $\begin{array}{l}\text { Relapsed or refractory } \\
\text { aggressive B cell } \\
\text { lymphomas }\end{array}$ \\
\hline NCT03219671 & $\|$ & Nivolumab and ipilimumab in classical Kaposi sarcoma & $\begin{array}{l}\text { Nivolumab } \\
\text { Ipilimumab }\end{array}$ & Classic Kaposi sarcoma \\
\hline
\end{tabular}

Abbreviations: ICIs immune checkpoint inhibitors, HPV human papillomavirus, $H B V$ hepatitis B virus, $H C V$ hepatitis $C$ virus, EBV Epstein-Barr virus, $H H V-8$ human herpesvirus type 8, HTLV-1 human T cell lymphotropic virus type 1, R/M recurrent and/or metastatic, GYN cancers cervical, vaginal, and vulvar cancers, SCCA squamous cell carcinoma of the anal canal, HCC hepatocellular carcinoma, NPC nasopharyngeal carcinoma, GC gastric cancer, NHL non-Hodgkin lymphoma

the Keynote-028 trial [12], providing a new treatment option for cervical cancer. In this study, the overall response rate (ORR) was 17\% (95\% CI 5-37\%). However, the HPV infection status of patients was not clear. A study (CheckMate358/NCT02488759) exploring the safety and efficacy of nivolumab in virus-associated cancers is being undertaken. In CheckMate358 [13], adults with cervical, vaginal, and vulvar cancers were eligible to receive nivolumab until progression or unacceptable toxicity. Of 24 treated patients, ORR was $20.8 \%$ and disease control rate $(\mathrm{CR}+\mathrm{PR}+\mathrm{SD})$ was $70.8 \%$ at a median follow-up of 31 weeks. All responses were in patients with cervical cancer and were observed independent of HPV status. Nivolumab has shown encouraging therapeutic effect in patients with cervical cancer and is worthy of further evaluation in these patients.

Squamous cell carcinoma of the anal canal (SCCA) is an uncommon malignancy associated with HPV infection. The treatment of anal cancer depends on accurate staging, and chemo-radiotherapy is the main treatment for most patients [30]. A single-arm, multicenter, phase II trial (NCI-9673/NCT02314169) studied the therapeutic effect of nivolumab in patients with metastatic SCCA [14]. Among the 37 patients who were enrolled and received nivolumab, the response rate was $24 \%$ (95\% CI 15-33). Given the high prevalence of HPV in SCCA and HPV was detected in all tested specimens in this study, the interaction of HPV with the tumor microenvironment could be responsible for the immune response.

Head and neck squamous cell carcinoma (HNSCC) comprises the majority of head and neck cancers and represents a heterogeneous group of tumors that arise from the squamous epithelium of the oral cavity, oropharynx, larynx, and hypopharynx [31]. In addition to the established risk factors such as smoking and alcohol consumption, HPV infection has become an important factor in the epidemiology and prognosis of HNSCC, mainly in oropharyngeal cancer [32,33]. The most recent development in the treatment of HNSCC is immunotherapy. A clinical trial (Keynote-012), which evaluated the safety and antitumor activity of pembrolizumab in patients with recurrent or metastatic (R/M) HNSCC, published results recently [15]. Sixty patients with HNSCC were enrolled and treated: 23 (38\%) patients were HPV-positive and 37 (62\%) were HPV-negative. The proportion of patients with an overall response by central imaging review was $18 \%$ (95\% CI 8-32) in all patients, $25 \%$ (95\% CI 7-52) in HPV-positive patients, and 14\% (95\% CI 4-32) in HPVnegative patients. Another clinical trial (NCT02207530) is an international, multi-institutional, single-arm study [16], which evaluated durvalumab in patients with platinumrefractory R/M HNSCC. Among evaluable patients, ORR was $16.2 \%$ (95\% CI 9.9-24.4), 29.4\% (95\% CI 15.1-47.5) among HPV-positive patients, and 10.8\% (95\% CI $4.4-$ 20.9) in HPV-negative patients. Therefore, in HPVpositive HNSCC, the treatment of ICIs was seemingly more effective. This is consistent with previous reports that biological features of HPV-related head and neck cancers contribute to improved response [34-36]. In a systematic review evaluating the efficacy of ICIs on HNSCC [37], five studies analyzing the OS or the PFS stratified according to HPV-status were included. Four [15, 38-40] of the five studies demonstrated a higher OS or PFS in HPVpositive patients compared to HPV-negative patients. One 
study [41] found no difference in OS and PFS between the two subgroups.

\section{HBV or HCV-related hepatocellular carcinoma}

Hepatocellular carcinoma (HCC) is one of the most frequently occurring cancers in the world and ranks third in global incidence [1]. HCC usually occurs in the setting of chronic liver inflammation and is mainly induced by viral hepatitis infection (HBV or HCV). Treatment of HCC including surgical resection, liver transplantation, and systemic therapy varies based on the stage of disease. However, only a small number of patients are suitable for surgical resection due to the extent of disease or poor liver function, and systemic treatment with sorafenib has displayed a comparatively modest role [42]. Therefore, there is an urgent need for new and better systemic therapy for HCC.

In a randomized, double-blind, placebo-controlled study (NCT00703469), the antivirus potential of BMS-936558 (MDX-1106/nivolumab) was explored in patients with chronic HCV infection [17]. Of the 54 patients who were treated (45 BMS-936558, nine placebo), clinical response (serum HCV RNA decline at least two consecutive visits) was observed in six patients (five BMS-936558, one placebo). There was no significant difference in clinical response rates between the nivolumab group (11.1\%) and the placebo group (11.1\%). Another clinical trial (NCT01008358) was to evaluate the antitumor and antivirus effect of tremelimumab in patients with $\mathrm{HCC}$ and chronic HCV infection [18]. Twenty patients were assessable for toxicity and virus response, and 17 were assessable for tumor response. As a result, the partial response rate was $17.6 \%$ and disease control rate was $76.4 \%$. A significant drop in virus load was observed. This antivirus effect was associated with an enhanced specific anti-HCV immune response, supporting further research on the anticancer effect of tremelimumab.

Studies have shown that the killing of tumors by direct methods (known as ablation) can result in the immune system being activated or switched on [19, 43]. ICIs may enhance this effect of anticancer therapy by activating the immune system to recognize and kill residual cancer lesions. Here, a study (NCT01853618) aimed to demonstrate that whether tremelimumab could be combined with ablation safely and feasibly [19]. Thirty-two patients with HCC were enrolled. Five of 19 evaluable patients (26.3\%) achieved a confirmed partial response, and 12 of 14 patients $(85.7 \%)$ with quantifiable HCV experienced a marked reduction in virus load. Therefore, tremelimumab in combination with tumor ablation is a potential new treatment for patients with advanced HCC, leading to the accumulation of $\mathrm{CD} 8+\mathrm{T}$ cells and the reduction in $\mathrm{HCV}$ virus load.
In September 2017, FDA approved nivolumab for liver cancer as a second line treatment after failure of sorafenib based on the data of CheckMate040 [20]. In the multi-cohort trial, 262 adults with advanced HCC were treated. In the dose-escalation phase, cohorts included 23 patients without virus hepatitis and 25 patients with HCV or HBV infection. The ORR was 15\% (95\% CI 628 ) in the dose-escalation phase, including three complete responses and four partial responses. In the dose-expansion phase, 214 patients with advanced HCC were distributed in different cohorts: 56 patients were not infected with HCV or HBV and had not been treated with sorafenib previously or were intolerant, 57 had disease progression on sorafenib, and 101 patients were infected with HCV or HBV. An objective response was observed in 42 patients (20\%; 95\% CI 15-26) in the dose-expansion phase. The response rate across all cohorts was reported in 14-20\% of HBV or HCV infected patients and 21-23\% of uninfected patients. Disease control was seen in $55-66 \%$ of patients infected with HBV or $\mathrm{HCV}$ and $61-75 \%$ of patients without viral hepatitis. It seems that the therapeutic effect of ICIs was not significantly different between the cohort with viral infection and the cohort without viral infection.

\section{EBV-associated cancers}

EBV, also called human gamma-herpesvirus 4 (HHV-4), causes chronic latent infection with lifelong persistence in about $95 \%$ of the world population [44]. It is associated with several kinds of human neoplasms, such as malignant lymphoma, nasopharyngeal carcinoma (NPC), and gastric cancer (GC).

EBV-associated NPC is one of the most common head and neck malignancies, and unfortunately, $70 \%$ of NPC patients have locally advanced disease at initial diagnosis. Nasopharyngectomy is one established treatment option for locally recurrent NPC [45]. Surgical procedures include traditional open methods, endoscopic nasopharyngectomy, and minimally invasive methods for nasopharyngeal resection using robotics. Radiotherapy alone and concurrent chemo-radiotherapy are important treatment approaches for NPC, but they have a limited effect on patients with locally advanced or distantly metastatic disease [46-48]. With an increasing understanding of the complex interaction between EBV, NPC, and the host immune system, ICIs appears to be a promising approach for the treatment of EBV-associated NPC [49].

A multinational study (NCI-9742) evaluated the antitumor activity of nivolumab in NPC [21]. In this study, patients with R/M NPC were treated with nivolumab until disease progression and plasma-based biomarkers were investigated. A total of 44 patients were evaluated and the ORR was $20.5 \%$. There was no statistical correlation between ORR and plasma EBV DNA clearance. 
Even so, the promising result of nivolumab in R/M NPC has driven interest in exploring the use of ICIs in EBVassociated NPC. Another clinical trial (Keynote-028/ NCT02054806) is a nonrandomized, multi-cohort trial of pembrolizumab in patients with PD-L1-positive advanced solid tumors [22]. Twenty-seven patients with R/ $M$ NPC received pembrolizumab up to two years or until disease progression or unacceptable toxicity. Partial response and stable disease were observed in seven and 14 patients, respectively. The ORR was $25.9 \%$ (95\% CI 11.1-46.3) over a median follow-up of 20 months. However, the study did not clearly indicate the viral infection status of patients.

EBV, originally discovered through its association with Burkitt lymphoma, is etiologically linked to a wide range of lymphoproliferative lesions and malignant lymphomas of $\mathrm{B}, \mathrm{T}$, and NK cell origin [50]. In a study involving seven patients with relapsed or refractory NK/T cell lymphoma, pembrolizumab proved to be effective [23]. After a median of seven cycles of pembrolizumab and a follow-up of a median of six months, five patients (71.4\%) achieved a complete response, with two having molecular remission (undetectable EBV DNA). This suggested that pembrolizumab was a potent strategy for NK/T cell lymphomas failing L-asparaginase regimens. Another clinical trial [24] published result recently, mainly comparing the efficacy of pembrolizumab between EBV-positive and EBV-negative relapsed or refractory non-Hodgkin lymphomas (NHL) in 30 patients. In this study, seven patients with EBV-positive NHL showed a response including NK/T cell lymphoma (44\%) and primary mediastinal B cell lymphoma (25\%), whereas EBV-negative subtypes such as diffuse large B cell lymphoma and T-lymphoblastic lymphoma did not respond. In addition, high PD-L1 expression (positive staining $>50 \%$ of tumor cells) was found in NK/T cell lymphoma and primary mediastinal B cell lymphoma than other subtypes. Thus, PD-L1 expression was significantly higher $(p<0.001)$ in EBV-positive (56\%) than EBVnegative NHL (11\%). It is anticipated that the better therapeutic effect of ICIs in EBV-positive lymphoma may be related to high expression of PD-L1.

In addition, EBV-positive gastric cancer (GC) is also under our consideration. Most recently, extremely high ORR (100\%) of pembrolizumab was reported in six patients with EBV-positive metastatic GC [25]. However, another study evaluated the effect of nivolumab showing that 25\% EBV-positive advanced GC achieved an objective response [26]. Therefore, EBV status as a predictor of treatment outcome should be evaluated in a larger cohort.

\section{Other carcinogenic viruses}

Other viruses that induce cancers include HIV, HTLV-1, and HHV-8. Among them, HIV is special in attributable risk calculations because its increased cancer risk only combine with other carcinogenic infectious factors [51]. A systematic review [27] was conducted to summarize the efficacy of ICIs therapy in HIV-positive cancers. Among 34 patients with known paired pretreatment and posttreatment HIV loads, HIV remained suppressed in 26 of the 28 (93\%) with undetectable HIV load. ORR in these HIV-related patients was $30 \%$ for non-small cell lung cancer, $27 \%$ for melanoma, and $63 \%$ for Kaposi sarcoma. Therefore, ICIs may be an effective treatment option in this patient population. There are several clinical trials to assess the safety and efficacy of ICIs in HIVinfected patients. A placebo-controlled, dose-escalating study (NCT02028403) of BMS-936559 (anti-PD-L1 antibody) was conducted in HIV-1-infected adults [52]. The plasma HIV-1 RNA was detected by a single-copy assay. Of six men who received BMS-936559, the mean percentage of HIV-1 Gag-specific CD8+ T cells increased in two participants, illustrating single BMS-936559 infusions appeared to enhance HIV-1-specific immunity in participants. An open-label, multiple ascending dose study (NCT03407105) assessed the safety of ipilimumab and whether ipilimumab enhanced the immune response to HIV-1 in HIV-1-infected participants [53]. In this study, two participants $(8.3 \%)$ had a decrease from baseline HIV-1 RNA, while 14 participants (58.3\%) had an increase from baseline HIV-1 RNA. Ipilimumab was well tolerated and was associated with variations in HIV-1 RNA. However, the mechanisms underlying the increased variation in HIV-1 RNA is unclear and needs further study.

In addition, HTLV-1 is a retrovirus of the human Tlymphotropic virus family that has been related with several kinds of diseases including aggressive adult $\mathrm{T}$ cell lymphoma (ATL) and HTLV-1-associated myelopathy [54]. HHV-8 is also known as Kaposi's sarcoma-associated herpesvirus (KSHV) and causes Kaposi sarcoma commonly occurring with acquired immune deficiency syndrome (AIDS) . Clinical trials of these viruses were also listed in Table 2.

\section{Conclusions}

At present, immunotherapy is widely use clinically, but is not always effective. It is not wise to administer immunotherapy without knowing the genetic background of the patient [55]. We need to screen out biomarkers to anchor which person is suitable for the application of checkpoint inhibitors. Future studies should focus on identifying biomarkers, such as virus infection status, to improve patient selection and help predict response. This article focuses on patients with viral-associated cancers and explores the therapeutic effects of ICIs.

In virus-induced cancers, the mechanisms by which viruses induce cancers are different, producing different mutation loads in tumors [44, 56-58]. Carcinogenic virus devastates host cellular structure, resulting in the 
engagement of virus DNA and host cell factors and the induction of DNA damage response (DDR). DDR increases their mutational rate, accelerates host chromosomal alteration, and as a consequence, facilitates virus replication $[59,60]$. EBV and HPV are two examples that promote DDR and activate mutation. It has been reported that the mutation load determines the sensitivity of the tumor to PD-1 blockade [61]. Therefore, ICIs have different therapeutic effects on virus-related cancers.

In addition, the interplay of immune checkpoints and their ligands is complex, occurring at different stages of $\mathrm{T}$ cell activation and function. Similarly, they work at different stages of tumorigenesis [62]. In virus-associated cancers, expression of viral oncoproteins makes these tumors an effective target for ICIs. PD-1 is a T cell co-inhibitory receptor, which is expressed on multiple immune cells, including T cells, B cells, natural killer cells, dendritic cells, and monocytes. When it binds to its ligands, PD-L1 or PD-L2, the activation and differentiation of cytotoxic T cell are both downregulated [63]. PD-L1 expression levels are found to be increased in various cancers, providing an additional pathway for immune evasion by inactivation of $\mathrm{T}$ cells [64-69]. On the other hand, PD-L1 expression is a controversial prognostic factor in different preclinical trials evaluating the potential role of ICIs in cancers. Multiple studies have shown that PD-L1 overexpression is present in virus-infected cancers compared to non-virusinfected cancers [70-72]. For example, EBV-induced NPC expresses higher levels of PD-L1 compare to EBVnegative nasopharyngeal carcinoma [70]. Given the abundant evidence for immune exhaustion in chronic virus infections and virus-associated malignancies $[62,73]$, anti-PD-L1 blockers deserve to be investigated as a therapeutic strategy in virus-associated cancers.

Through the above clinical trials, there is no clear statistical significance indicates whether ICIs are more effective in virus-infected population than non-virus infections. However, the efficacy of ICIs in treating virus-associated cancers is rather promising. These virus-induced cancers present a specific immunological profile that virus-positive cancers often exhibit increased infiltration of cytolytic cell types compared to their virus-negative counterparts, and their responses to ICIs are expected to be different from other cancers [4]. More clinical trials are needed to evaluate the value of viral infections as a predictive factor in treatment based on checkpoint inhibitors. We can expect that if more clinical trial results are published, the efficacy of ICIs in virus-associated cancers will be highlighted and better application prospects will be developed.

\section{Abbreviations}

AIDS: Acquired immune deficiency syndrome; Cl: Confidence interval; CTLA4: Cytotoxic T lymphocyte antigen 4; DDR: DNA damage response; EBV: Epstein-Barr virus; FDA: Food and Drug Administration; HBV: Hepatitis B virus; HCC: Hepatocellular carcinoma; HCV: Hepatitis C virus; HHV-8: Human herpesvirus type 8; HNSCC: Head and neck squamous cell carcinoma; HPV: Human papillomavirus; HTLV-1: Human T cell lymphotropic virus type 1; IARC: International Agency for Research on Cancer; ICls: Immune checkpoint inhibitors; KSHV: Kaposi's sarcoma-associated herpesvirus; NHL: Non-Hodgkin lymphomas; NPC: Nasopharyngeal carcinoma; ORR: Overall response rate; PD-1: Programmed death 1; R/M HNSCC: Recurrent or metastatic head and neck squamous cell carcinoma; SD: Stable disease; Treg: Regulatory T cell

\section{Publisher's Note}

Springer Nature remains neutral with regard to jurisdictional claims in published maps and institutional affiliations.

\section{Acknowledgements}

Not applicable.

\section{Authors' contributions}

PG performed the selection of literature, drafted the manuscript, and prepared the tables. Others participated in the discussions and revisions. PW and DM revised the manuscript. All authors contributed to this manuscript. All authors read and approved the final manuscript.

\section{Funding}

This work was supported by National Natural Science Foundation of China (81630060, 81772775), National Basic Research Program (973 Program), Ministry of Science and Technology of the People's Republic of China (2015CB553903), and the research-oriented clinician funding program of Tongji Medical College, Huazhong University of Science and Technology.

Availability of data and materials

Not applicable.

Ethics approval and consent to participate

Not applicable.

Consent for publication

Not applicable.

\section{Competing interests}

The authors declare that they have no competing interests.

\section{Author details}

${ }^{1}$ Cancer Biology Research Center (Key Laboratory of the Ministry of Education), Tongji Hospital, Tongji Medical College, Huazhong University of Science and Technology, Wuhan, Hubei, China. ${ }^{2}$ Department of Gynecologic Oncology, Tongji Hospital, Tongji Medical College, Huazhong University of Science and Technology, Wuhan, Hubei, China.

Received: 27 March 2019 Accepted: 14 May 2019

Published online: 10 June 2019

\section{References}

1. Bray F, Ferlay J, Soerjomataram I, Siegel RL, Torre LA, Jemal A. Global cancer statistics 2018: GLOBOCAN estimates of incidence and mortality worldwide for 36 cancers in 185 countries. CA Cancer J Clin. 2018:68:394-424.

2. Varn FS, Schaafsma E, Wang Y, Cheng C. Genomic characterization of six virusassociated cancers identifies changes in the tumor immune microenvironment and altered genetic programs. Cancer Res. 2018;78:6413-23.

3. Plummer M, de Martel C, Vignat J, Ferlay J, Bray F, Franceschi S. Global burden of cancers attributable to infections in 2012: a synthetic analysis. Lancet Glob Health. 2016:4:e609-16.

4. Mesri EA, Feitelson MA, Munger K. Human viral oncogenesis: a cancer hallmarks analysis. Cell Host Microbe. 2014;15:266-82.

5. Krump NA, You J. Molecular mechanisms of viral oncogenesis in humans. Nat Rev Microbiol. 2018;16:684-98.

6. Samra B, Tam E, Baseri B, Shapira I. Checkpoint inhibitors in head and neck cancer: current knowledge and perspectives. J Investig Med. 2018:66:1023-30.

7. De Felice F, Marchetti C, Palaia I, Ostuni R, Muzii L, Tombolini V, et al. Immune check-point in cervical cancer. Crit Rev Oncol Hematol. 2018;129:40-3.

8. Kudo M. Immune checkpoint inhibition in hepatocellular carcinoma: basics and ongoing clinical trials. Oncology. 2017;92(Suppl 1):50-62. 
9. Popovic LS, Matovina-Brko G, Popovic M. Checkpoint inhibitors in the treatment of urological malignancies. ESMO Open. 2017;2:e000165.

10. Weber MM, Fottner $C$. Immune checkpoint inhibitors in the treatment of patients with neuroendocrine neoplasia. Oncol Res Treat. 2018;41:306-12.

11. Ventriglia J, Paciolla I, Pisano C, Cecere SC, Di Napoli M, Tambaro R, et al. Immunotherapy in ovarian, endometrial and cervical cancer: State of the art and future perspectives. Cancer Treat Rev. 2017;59:109-16.

12. Frenel JS, Le Tourneau C, O'Neil B, Ott PA, Piha-Paul SA, Gomez-Roca C, et al. Safety and efficacy of pembrolizumab in advanced, programmed death ligand 1-positive cervical cancer: results from the phase Ib KEYNOTE-028 trial. J Clin Oncol. 2017;35:4035-41.

13. Hollebecque A, Meyer T, Moore KN, Machiels JPH, De Greve J, Lopez-Picazo JM, et al. An open-label, multicohort, phase 1/II study of nivolumab in patients with virus-associated tumors (CheckMate 358): efficacy and safety in recurrent or metastatic (R/M) cervical, vaginal, and vulvar cancers. J Clin Oncol. 2017:35.

14. Morris VK, Salem ME, Nimeiri H, labal S, Singh P, Ciombor K, et al. Nivolumab for previously treated unresectable metastatic anal cancer (NC19673): a multicentre, single-arm, phase 2 study. Lancet Oncol. 2017;18:446-53.

15. Seiwert TY, Burtness B, Mehra R, Weiss J, Berger R, Eder JP, et al. Safety and clinical activity of pembrolizumab for treatment of recurrent or metastatic squamous cell carcinoma of the head and neck (KEYNOTE-012): an openlabel, multicentre, phase 1b trial. Lancet Oncol. 2016;17:956-65.

16. Zandberg DP, Algazi AP, Jimeno A, Good JS, Fayette J, Bouganim N, et al. Durvalumab for recurrent or metastatic head and neck squamous cell carcinoma: Results from a single-arm, phase II study in patients with $>/=$ 25\% tumour cell PD-L1 expression who have progressed on platinum-based chemotherapy. Eur J Cancer. 2019;107:142-52

17. Gardiner D, Lalezari J, Lawitz E, DiMicco M, Ghalib R, Reddy KR, et al. A randomized, double-blind, placebo-controlled assessment of BMS-936558, a fully human monoclonal antibody to programmed death-1 (PD-1), in patients with chronic hepatitis C virus infection. PLoS One. 2013;8:e63818.

18. Sangro B, Gomez-Martin C, de la Mata M, Inarrairaegui M, Garralda E, Barrera P, et al. A clinical trial of CTLA-4 blockade with tremelimumab in patients with hepatocellular carcinoma and chronic hepatitis C. J Hepatol. 2013;59:81-8.

19. Duffy AG, Ulahannan SV, Makorova-Rusher O, Rahma O, Wedemeyer H, Pratt $\mathrm{D}$, et al. Tremelimumab in combination with ablation in patients with advanced hepatocellular carcinoma. J Hepatol. 2017;66:545-51.

20. El-Khoueiry AB, Sangro B, Yau T, Crocenzi TS, Kudo M, Hsu C, et al. Nivolumab in patients with advanced hepatocellular carcinoma (CheckMate 040): an openlabel, non-comparative, phase 1/2 dose escalation and expansion trial. Lancet. 2017;389:2492-502.

21. Ma BBY, Lim WT, Goh BC, Hui EP, Lo KW, Pettinger A, et al. Antitumor activity of nivolumab in recurrent and metastatic nasopharyngeal carcinoma: an international, multicenter study of the Mayo Clinic Phase 2 Consortium (NCl-9742). J Clin Oncol. 2018;36:1412-8.

22. Hsu C, Lee SH, Ejadi S, Even C, Cohen RB, Le Tourneau C, et al. Safety and antitumor activity of pembrolizumab in patients with programmed deathligand 1-positive nasopharyngeal carcinoma: results of the KEYNOTE-028 study. J Clin Oncol. 2017:35:4050-6.

23. Kwong YL, Chan TSY, Tan D, Kim SJ, Poon LM, Mow B, et al. PD1 blockade with pembrolizumab is highly effective in relapsed or refractory NK/T-cell lymphoma failing L-asparaginase. Blood. 2017;129:2437-42.

24. Kim SJ, Hyeon J, Cho I, Ko YH, Kim WS. Comparison of efficacy of pembrolizumab between Epstein-Barr virus-positive and -negative relapsed or refractory non-hodgkin lymphomas. Cancer Res Treat. 2019;51:611-22.

25. Kim ST, Cristescu R, Bass AJ, Kim KM, Odegaard JI, Kim K, et al. Comprehensive molecular characterization of clinical responses to PD-1 inhibition in metastatic gastric cancer. Nat Med. 2018;24:1449-58.

26. Mishima S, Kawazoe A, Nakamura Y, Sasaki A, Kotani D, Kuboki Y, et al. Clinicopathological and molecular features of responders to nivolumab for patients with advanced gastric cancer. J Immunother Cancer. 2019;7:24.

27. Cook MR, Kim C. Safety and efficacy of immune checkpoint inhibitor therapy in patients with hiv infection and advanced-stage cancer: a systematic review. JAMA Oncol. 2019

28. Otter S, Whitaker S, Chatterjee J, Stewart A. The human papillomavirus as a common pathogen in oropharyngeal, anal and cervical cancers. Clin Oncol (R Coll Radiol). 2019;31:81-90.

29. Jemal A, Simard EP, Dorell C, Noone AM, Markowitz LE, Kohler B, et al. Annual Report to the Nation on the Status of Cancer, 1975-2009, featuring the burden and trends in human papillomavirus (HPV)-associated cancers and HPV vaccination coverage levels. J Natl Cancer Inst. 2013;105:175-201.
30. Symer MM, Yeo HL. Recent advances in the management of anal cancer. F1000Research. 2018:7.

31. Solomon B, Young RJ, Rischin D. Head and neck squamous cell carcinoma: Genomics and emerging biomarkers for immunomodulatory cancer treatments. Semin Cancer Biol. 2018;52:228-40.

32. Gillison ML, Chaturvedi AK, Anderson WF, Fakhry C. Epidemiology of human papillomavirus-positive head and neck squamous cell carcinoma. J Clin Oncol. 2015;33:3235-42

33. Ang KK, Harris J, Wheeler R, Weber R, Rosenthal DI, Nguyen-Tan PF, et al. Human papillomavirus and survival of patients with oropharyngeal cancer. New England J Med. 2010;363:24-35.

34. Cleary C, Leeman JE, Higginson DS, Katabi N, Sherman E, Morris L, et al. Biological features of human papillomavirus-related head and neck cancers contributing to improved response. Clin Oncol (R Coll Radiol). 2016;28:467-74.

35. Fakhry C, Westra WH, Li S, Cmelak A, Ridge JA, Pinto H, et al. Improved survival of patients with human papillomavirus-positive head and neck squamous cell carcinoma in a prospective clinical trial. J Natl Cancer Inst. 2008;100:261-9.

36. Lassen P, Eriksen JG, Hamilton-Dutoit S, Tramm T, Alsner J, Overgaard J. Effect of HPV-associated p16INK4A expression on response to radiotherapy and survival in squamous cell carcinoma of the head and neck. J Clin Oncol. 2009;27:1992-8.

37. Ghanizada M, Jakobsen KK, Gronhoj C, von Buchwald C. The effects of checkpoint inhibition on head and neck squamous cell carcinoma: a systematic review. Oral Oncol. 2019;90:67-73.

38. Hanna GJ, Lizotte P, Cavanaugh M, Kuo FC, Shivdasani P, Frieden A, et al. Frameshift events predict anti-PD-1/L1 response in head and neck cancer. JCl Insight. 2018;3.

39. Ferris RL, Blumenschein G Jr, Fayette J, Guigay J, Colevas AD, Licitra L, et al. Nivolumab vs investigator's choice in recurrent or metastatic squamous cell carcinoma of the head and neck: 2-year long-term survival update of CheckMate 141 with analyses by tumor PD-L1 expression. Oral Oncol. 2018;81:45-51.

40. Ferris RL, Blumenschein G Jr, Fayette J, Guigay J, Colevas AD, Licitra L, et al. Nivolumab for recurrent squamous-cell carcinoma of the head and neck. N Engl J Med. 2016;375:1856-67.

41. Bauml J, Seiwert TY, Pfister DG, Worden F, Liu SV, Gilbert J, et al. Pembrolizumab for platinum- and cetuximab-refractory head and neck cancer: results from a single-arm, phase II study. J Clin Oncol. 2017:35:1542-9.

42. Cheng AL, Kang YK, Chen Z, Tsao CJ, Qin S, Kim JS, et al. Efficacy and safety of sorafenib in patients in the Asia-Pacific region with advanced hepatocellular carcinoma: a phase III randomised, double-blind, placebo-controlled trial. Lancet Oncol. 2009;10:25-34.

43. Greten TF, Duffy AG, Korangy F. Hepatocellular carcinoma from an immunologic perspective. Clin Cancer Res. 2013;19:6678-85.

44. Yin H, Qu J, Peng Q, Gan R. Molecular mechanisms of EBV-driven cell cycle progression and oncogenesis. Med Microbiol Immunol. 2018.

45. Lam WKJ, Chan JYK. Recent advances in the management of nasopharyngeal carcinoma. F1000Res. 2018;7.

46. Jin Y, Cai XY, Shi YX, Xia XY, Cai YC, Cao Y, et al. Comparison of five cisplatin-based regimens frequently used as the first-line protocols in metastatic nasopharyngeal carcinoma. J Cancer Res Clin. 2012;138:1717-25.

47. Goto Y, Kodaira T, Fuwa N, Mizoguchi N, Nakahara R, Nomura M, et al. Alternating chemoradiotherapy in patients with nasopharyngeal cancer: prognostic factors and proposal for individualization of therapy. J Radiat Res. 2013;54:98-107.

48. Dou HQ, Hu DY, Lam C, Liu YS, Wang XW, Zhang WD. Retrospective analysis of results of treatment for nasopharyngeal carcinoma in Macao. Chinese J Cancer Res. 2014;26:148-58.

49. Hong M, Tang K, Qian J, Deng H, Zeng M, Zheng S, et al. Immunotherapy for EBV-associated nasopharyngeal carcinoma. Crit Rev Oncog. 2018;23:219-34.

50. Shannon-Lowe C, Rickinson AB, Bell Al. Epstein-Barr virus-associated lymphomas. Philos Trans R Soc Lond B Biol Sci. 2017;372.

51. IARC. A review of human carcinogens. In: Biological agents. Volume $100 \mathrm{~B}$, edn; 2012. p. 1-441.

52. Gay CL, Bosch RJ, Ritz J, Hataye JM, Aga E, Tressler RL, et al. Clinical trial of the anti-PD-L1 antibody BMS-936559 in HIV-1 infected participants on suppressive antiretroviral therapy. J Infect Dis. 2017:215:1725-33.

53. Colston E, Grasela D, Gardiner D, Bucy RP, Vakkalagadda B, Korman AJ, et al. An open-label, multiple ascending dose study of the anti-CTLA-4 antibody ipilimumab in viremic HIV patients. PLoS One. 2018;13:e0198158.

54. Tagaya Y, Gallo RC. The exceptional oncogenicity of HTLV-1. Front Microbiol. 2017:8:1425 
55. Spencer CN, Wells DK, LaVallee TM. It is a capital mistake to theorize who to treat with checkpoint inhibitors before one has data. Trends in Cancer. 2019;5:79-82.

56. Walboomers JMM, Jacobs MV, Manos MM, Bosch FX, Kummer JA, Shah KV, et al. Human papillomavirus is a necessary cause of invasive cervical cancer worldwide. J Pathol. 1999;189:12-9.

57. Arzumanyan A, Reis HMGPV, Feitelson MA. Pathogenic mechanisms in HBV- and HCV-associated hepatocellular carcinoma. Nature Reviews Cancer. 2013;13:123-35.

58. Kobayashi K, Hisamatsu K, Suzui N, Hara A, Tomita H, Miyazaki T. A Review of HPV-related head and neck cancer. J Clin Med. 2018;7.

59. McFadden K, Luftig MA. Interplay between DNA tumor viruses and the host DNA damage response. Curr Top Microbiol Immunol. 2013;371:229-57.

60. Turnell AS, Grand RJ. DNA viruses and the cellular DNA-damage response. J Gen Virol. 2012;93:2076-97.

61. Rizvi NA, Hellmann MD, Snyder A, Kvistborg P, Makarov V, Havel JJ, et al. Cancer immunology. Mutational landscape determines sensitivity to PD-1 blockade in non-small cell lung cancer. Science. 2015;348:124-8.

62. Dyck L, Mills KHG. Immune checkpoints and their inhibition in cancer and infectious diseases. Eur J Immunol. 2017;47:765-79.

63. Pardoll DM. The blockade of immune checkpoints in cancer immunotherapy. Nat Rev Cancer. 2012;12:252-64.

64. Yang W, Song Y, Lu Y-L, Sun J-Z, Wang H-W. Increased expression of programmed death (PD)-1 and its ligand PD-L1 correlates with impaired cell-mediated immunity in high-risk human papillomavirus-related cervical intraepithelial neoplasia. Immunology. 2013;139:513-22.

65. Heeren AM, Punt S, Bleeker MCG, Gaarenstroom KN, van der Velden J, Kenter GG, et al. Prognostic effect of different PD-L1 expression patterns in squamous cell carcinoma and adenocarcinoma of the cervix. Modern Pathology. 2016;29:753-63.

66. Yang W, Lu YP, Yang YZ, Kang JR, Jin YD, Wang HW. Expressions of programmed death (PD)-1 and PD-1 ligand (PD-L1) in cervical intraepithelial neoplasia and cervical squamous cell carcinomas are of prognostic value and associated with human papillomavirus status. J Obstet Gynaecol Res. 2017:43:1602-12.

67. Schneider S, Kadletz L, Wiebringhaus R, Kenner L, Selzer E, Füreder T, et al. PD-1 and PD-L1 expression in HNSCC primary cancer and related lymph node metastasis - impact on clinical outcome. Histopathology. 2018;73:573-84.

68. Qu Y, Wang D, Yang L, Liu HY, Cui W, Che YQ. Expression and clinical significance of programmed death ligand 1 in nasopharyngeal carcinoma. Mol Clin Oncol. 2018

69. Maruse Y, Kawano S, Jinno T, Matsubara R, Goto Y, Kaneko N, et al. Significant association of increased PD-L1 and PD-1 expression with nodal metastasis and a poor prognosis in oral squamous cell carcinoma. Int J Oral Maxillofac Surg. 2018:47:836-45.

70. Fang W, Zhang J, Hong S, Zhan J, Chen N, Qin T, et al. EBV-driven LMP1 and IFN- $\gamma$ up-regulate PD-L1 in nasopharyngeal carcinoma: implications for oncotargeted therapy. Oncotarget. 2014;5:12189-202.

71. Green MR, Rodig S, Juszczynski P, Ouyang J, Sinha P, O'Donnell E, et al. Constitutive AP-1 activity and EBV infection induce PD-11 in Hodgkin lymphomas and posttransplant lymphoproliferative disorders: implications for targeted therapy. Clin Cancer Res. 2012;18:1611-8.

72. Bass AJ, Thorsson V, Shmulevich I, Reynolds SM, Miller M, Bernard B, et al. Comprehensive molecular characterization of gastric adenocarcinoma. Nature. 2014;513:202-9.

73. Lyford-Pike S, Peng S, Young GD, Taube JM, Westra WH, Akpeng B, et al. Evidence for a role of the PD-1:PD-L1 pathway in immune resistance of HPV-associated head and neck squamous cell carcinoma. Cancer Res. 2013; 73:1733-41.

Ready to submit your research? Choose BMC and benefit from:

- fast, convenient online submission

- thorough peer review by experienced researchers in your field

- rapid publication on acceptance

- support for research data, including large and complex data types

- gold Open Access which fosters wider collaboration and increased citations

- maximum visibility for your research: over $100 \mathrm{M}$ website views per year

At $\mathrm{BMC}$, research is always in progress.

Learn more biomedcentral.com/submissions 